\title{
COMBINED INOCULATION OF ARBUSCULAR MYCORRHIZAL FUNGI, PSEUDOMONAS FLUORESCENS AND TRICHODERMA SPP. FOR ENHANCING DEFENSE ENZYMES AND YIELD OF THREE PEPPER CULTIVARS
}

\author{
DUC, N. H. ${ }^{1}-$ MAYER, Z. ${ }^{1}-$ PÉK, Z. ${ }^{2}-$ HelYES, L. ${ }^{2}-$ POSTA, K..$^{1 *}$ \\ ${ }^{1}$ Institute of Genetics, Microbiology and Biotechnology, Szent István University \\ Páter Károly Street 1, Gödöllö H-2100, Hungary \\ ${ }^{2}$ Institute of Horticulture, Szent István University \\ Páter Károly Street 1, Gödöllö H-2100, Hungary \\ *Corresponding author \\ e-mail:Posta.Katalin@mkk.szie.hu \\ (Received $8^{\text {th }}$ Mar 2017; accepted 22 ${ }^{\text {nd }}$ May 2017)
}

\begin{abstract}
Field experiment was carried out at the experimental station of Szent István University, Gödöllö, Hungary to explore the impact of arbuscular mycorrhizal fungi only alone or together with Trichoderma and plant growth-promoting bacteria on defense enzymes and yield of three pepper varieties. The seven inoculation treatments consisting of arbuscular mycorrhizal fungi (AM), Trichoderma (Tri), plant growth promoting bacteria (Pse) and their combinations (AM+Tri; $\mathrm{AM}+\mathrm{Tri}+\mathrm{Pse}$; $\mathrm{AM}+\mathrm{Pse}$ ) together with three pepper hybrids and non-inoculation (control) plants were arranged in a randomized complete block design. Defense enzyme activities polyphenol oxidase (PPO), peroxidase (POD), superoxide dismutase (SOD), catalase (CAT) of various treated plants were measured just before flowering, representing the most sensitive stage of plants. The results showed that AM+Tri+Pse treatment enhanced the yield most among microbial inoculations. Highest yield was recorded in the triple treatment in Karpex cultivar, however, Karpia and Kaptur variety obtained more improved yield by microbial inoculations. Defense enzymes activities generally were most induced in the combination of three inoculants in cultivars whereas different responses in induction of defense enzymes were found in other microbial treatments, depending on specific interactions between microbe and pepper genotype. These results suggested that the triple application brought more benefits to the host plant.
\end{abstract}

Keywords: biofertilizers, Capsicum annuиm L., antioxidative enzymes, pepper productivity, pepper varieties

$\begin{array}{ll}\text { Abbreviations: } \\ \text { AM } & \text { Arbuscular mycorrhizal } \\ \text { AMF } & \text { Arbuscular mycorhizal fungi } \\ \text { Tri } & \text { Trichoderma } \\ \text { Pse } & \text { Pseudomonas fluorescens } \\ \text { DAT } & \text { Days after transplanting } \\ \text { ROS } & \text { Reactive oxygen species } \\ \text { PPO } & \text { Polyphenol oxidase } \\ \text { POD } & \text { Peroxidase } \\ \text { SOD } & \text { Superoxide dismutase } \\ \text { CAT } & \text { Catalase }\end{array}$

\section{Introduction}

Pepper (Capsicum annuum L.) is one of the main vegetables, cultivated worldwide and has important nutritional and economic values. It represents high pharmaceutical values due to its abundance of vitamins A, B6, C, E, K and minerals (manganese, 
potassium) moreover a very good source of dietary fiber (Malik et al., 2011; Yang et al., 2010; López et al., 2012).

Besides plant varieties, pepper production and quality are fluctuated due to various stress conditions (high temperature, drought, pathogens) which often cause up to $70 \%$ losses in yield giving a barrier in pepper production (Gajanayake et al., 2011).

There is a growing awareness of sustainable agriculture, how to minimize the damage, reduced chemical inputs and ensure protection of environmental stresses. The application of beneficial microbes could be an important technique giving environment friendly way to enhance yield of pepper and plant resistances to abiotic and biotic stresses.

Among effective microorganisms arbuscular mycorrhizal fungi (AMF) and plant growth promoting rhizobacteria together with Trichoderma are the most frequently used inoculants (Singh et al., 2011).

AMF can colonize $80 \%$ of terrestrial plant species including many important agricultural and horticultural plants (Smith and Read, 2008). There are important aspects from mycorrhizal colonization including improved seedling survival, increased growth and yield, uniformity of horticultural crops, and earlier and increased flowering (Azcón-Aguilar and Barea, 1997; Vosátka and Albrechtová, 2008; Gaur et al., 1998; Kaya et al., 2009; Russo and Perkins-Veazie, 2010). Furthermore, root colonization by AMF can improve the plant resistance to biotic or abiotic stresses (Pereira et al., 2015) through significant alterations in the hormonal balance and transcriptional profile, primary and secondary metabolisms (Jung et al., 2012; López-Ráez et al., 2010).

Similarly, plant growth promoting bacteria also contribute positively to plant fitness through direct and indirect mechanisms, induction of resistance by production of phytohormones, solubilization of inorganic phosphates, increased iron nutrition through iron-chelating siderophores and volatile compounds that affect the plant signaling pathways (Ahemad and Kibret, 2014; Lugtenberg and Kamilova, 2009).

Trichoderma spp. are free-living filamentous fungi and some of them are the most potent agents for the biocontrol of soil borne plant pathogens (Elad, 1996). It has been known for many years that they produce a wide range of antibiotic substances and that they parasitize other fungi (Sivasithamparam and Ghisalberti, 1998). In addition, they inhibit or degrade pectinases and other enzymes that are essential for plant-pathogenic fungi (Zimand et al., 1996).

The study of interactions between beneficial microorganisms associated with plant roots is important, because such interactions might either enhance or inhibit the beneficial effects of individual species. It has also been indicated that some Trichoderma strains may influence AM fungi activity (Martinez et al., 2004; MartínezMedina et al., 2009).

Several studies have demonstrated a positive effect of the dual or combined inoculation on plant performance in the presence as well as in the absence of plant pathogens (Datnoff et al., 1995; Siddiqui and Mahmood, 1996; Chandanie et al., 2009), while others reported a reduction in plant shoot and root dry weights (McAllister et al., 1994). Nonetheless, the studies on the interactions between Trichoderma spp. and AMF had contrast results such as antagonistic, neutral, and synergistic impacts on plants (Green et al., 1999; Martínez-Medina et al., 2009).

Although use of the beneficial microbes is widely investigated in many plants, little attention has been paid to defense enzyme activities induced by multiple application of the microbial inoculants and offered by different pepper hybrids under field conditions. 
Therefore, the aim of this study was to examine the potential of AM mixture, Trichoderma, Pseudomonas fluorescens and their combined applications for improvement of fruit yield and inducing defense enzymes (PPO, POD, SOD, CAT) in different pepper genotypes under field conditions following the practice.

\section{Materials and methods}

\section{Plant growth and experiment design}

Three sweet pepper (Capsicum annuum L.) hybrids, Karpia, Karpex and Kaptur were used for this study at the experimental station of Szent István University, Gödöllö, Hungary $\left(47.59^{\circ} \mathrm{N}\right.$ and $\left.19.35^{\circ} \mathrm{E}\right)$. The soil of the experimental station had brown forest soil, sandy loam in texture, consisting of $69 \%$ sand, $22 \%$ silt, and $9 \%$ clay, having chemical properties presented in Table 1. A moldboard plough to $25 \mathrm{~cm}$ depth was used for soil tillage after each harvesting time and conventional seedbeds were prepared by chisel plowing followed by disking.

Table 1. Chemical properties of the soil in the experiment.

\begin{tabular}{|c|c|c|c|c|c|c|c|c|c|c|c|c|c|c|}
\hline \multirow[t]{2}{*}{ pH } & \multirow{2}{*}{$\begin{array}{c}\mathrm{EC} \\
(\mathrm{mS} \\
\left.\mathrm{cm}^{-1}\right)\end{array}$} & \multirow{2}{*}{$\begin{array}{c}\text { Organic } \\
\text { matter } \\
(\%)\end{array}$} & $\begin{array}{c}\mathrm{NO}_{3} \\
(\mathbf{N})\end{array}$ & $\mathbf{P}_{2} \mathbf{O}_{5}$ & $\mathbf{K}_{2} \mathbf{O}$ & Ca & Mg & $\mathrm{Fe}$ & $\mathrm{Cu}$ & B & $\begin{array}{c}\mathrm{SO}_{4} \\
(\mathrm{~S})\end{array}$ & $\mathrm{Cl}$ & $\mathrm{HCO}_{3}$ & $\mathbf{N a}$ \\
\hline & & & \multicolumn{12}{|c|}{$\mathrm{mg} \mathrm{kg}^{-1}$} \\
\hline 7.1 & 0.254 & 1.61 & 15.6 & 36.0 & 60 & 140.3 & 24.3 & 208 & 7.6 & 0.5 & 4.0 & 0 & 534 & 10 \\
\hline
\end{tabular}

The average temperatures and precipitations were $12.8^{\circ} \mathrm{C}$ and $8.95 \mathrm{~mm}$ in May; $16.8^{\circ} \mathrm{C}, 7.2 \mathrm{~mm}$ in June; $18.7^{\circ} \mathrm{C}, 8.84 \mathrm{~mm}$ in July; $15.7^{\circ} \mathrm{C}, 11 \mathrm{~mm}$ in August; $12.6^{\circ} \mathrm{C}$, $8.21 \mathrm{~mm}$ in September 2014, respectively.

Seedlings of pepper varieties were propagated at the beginning of April in a greenhouse using special horticulture substrate [Klasmann TS3: 80\% white sphagnum peat and $20 \%$ frozen black sphagnum-peat, slow-release $14 \mathrm{~N}-16 \mathrm{P}-18 \mathrm{~K}(\mathrm{w} / \mathrm{w} / \mathrm{w})$ fertilizer, $\mathrm{pH}$ 6.00] for 7 weeks. Then the seedlings were transplanted on $16^{\text {th }}$ May, arranged in double rows with a distance of $0.8 \mathrm{~m}$ between beds, $0.3 \mathrm{~m}$ between the rows and $0.3 \mathrm{~m}$ between the plants. $72 \mathrm{~g}$ of NPK and $36 \mathrm{~g}$ of $\mathrm{Ca}\left(\mathrm{NO}_{3}\right)_{2}$ per square meter were applied for the whole season and drip irrigation was used to maintain substrate moisture content close to field capacity values $(20 \% \mathrm{w} / \mathrm{w})$ during the growth period.

All treatments including seven microbial inoculations and three cultivars were arranged in randomized complete block design. The seven microbial inoculations were arbuscular mycorrhizal fungi (AM), Trichoderma (Tri), plant growth promoting bacteria (Pse) and their combinations (AM+Tri; AM+Tri+Pse; AM+Pse) and non-inoculation (control) plants with 30 replications per treatment each cultivar.

Leaves at the same level from five different plants per treatment were collected at 29 days after transplanting (DAT) and kept in the $-80^{\circ} \mathrm{C}$ until enzyme assays. Roots from five plants per treatment were taken just before harvesting for estimation of mycorrhizal colonization rate. The pepper harvesting was performed randomly by hand at the biological maturity stage in August and evaluated for plants in each treatment. 


\section{Microbial inoculations}

Before transplanting mycorrhizal fungi in a commercial product Symbivit ${ }^{\circledR}$ (mixture of Glomus intraradices, $G$. mosseae, $G$. etunicatum, $G$. claroideum, $G$. microaggregatum, G. geosporum) produced by Symbiom Ltd. (Lanskroun, Czech Republic; www.symbiom.cz) was applied at $25 \mathrm{~g}$ of inoculum per pepper seedling into the planting hole and seedlings were planted immediately (AM treatment).

Trichoderma harzianum isolate (SzIE35) has previously been isolated and preserved in the collection of Szent István University. The isolate was cultured on Potato Dextrose Agar (PDA) at $25^{\circ} \mathrm{C}$ for 4 days and the inocula was produced in potato-dextrose broth shake culture at $(150 \mathrm{rpm})$ for 1 week at $25^{\circ} \mathrm{C} \pm 2{ }^{\circ} \mathrm{C}$. The cultures were filtered through a double layer of sterilized gauze and clean conidial suspension was prepared at the concentration of $10^{7} \mathrm{ml}^{-1}$. $10 \mathrm{ml}$ fresh prepared conidia with the volume of 0.2 liter sterile water were implemented to the seedlings 27 days after transplanting (Tri treatment).

Pseudomonas fluorescens isolate (PK17) originated from the collection of the Szent István University was prepared for plant growth-promoting bacteria inoculation. The PK17 inoculum was prepared by growing in liquid R2A medium (Difco) at $25^{\circ} \mathrm{C}$ for 36 $\mathrm{h}$, suspended in $0.1 \mathrm{M} \mathrm{MgSO}_{4}$ buffer, washed twice and re-suspended in distilled water at $10^{8} \mathrm{cfu}$ per $\mathrm{ml} .10 \mathrm{ml}$ fresh bacterium suspension was applied to the respective treatments $\left(10^{8} \mathrm{cfu} \mathrm{ml}^{-1}\right) 27$ days after transplanting (Pse treatment).

\section{Enzyme extraction and measurement of enzymes activities}

$0.5 \mathrm{~g}$ of frozen $\left(-80^{\circ} \mathrm{C}\right)$ leaf material of each sample from treatments was homogenized in liquid $\mathrm{N}_{2}$ with $3 \mathrm{ml}$ of $50 \mathrm{mM}$ Tris- $\mathrm{HCl}$ buffer ( $\mathrm{pH} 7.8$ ) containing $7.5 \%$ (w/v) polyvinyl-pyrrolidone $\mathrm{K} 25$ and $1 \mathrm{mM} \mathrm{Na} 2$ EDTA, and centrifuged at 10,000 $\mathrm{x} g$ for 20 minutes at $4^{\circ} \mathrm{C}$. The supernatants were used for measuring peroxidase, polyphenol oxidase, superoxide dismutase and catalase activities, the protein concentration of all leaf extracts was estimated according to the method of Bradford (1976).

Polyphenol oxidase (PPO, EC 1.10.3.1) activity was measured by modified Fehrmann and Dimond (1967) method. The $2.2 \mathrm{ml}$ of reaction mixture made up of 0.1 M sodium phosphate buffer ( $\mathrm{pH}$ 6.0), $1 \mathrm{mM} \mathrm{Na} \mathrm{a}_{2}$ EDTA, $20 \mathrm{mM}$ catechol with $200 \mu \mathrm{l}$ of the crude leaf extract was used to assay the enzyme activity at $400 \mathrm{~nm}$ in 10 minutes. Changes of absorbance per protein concentration per unit time was estimated.

Peroxidase (POD, EC 1.11.1.7) activity was determined by Rathmell and Sequeira (1974) method. Briefly, $10 \mu \mathrm{l}$ plant extract was added to $2.2 \mathrm{ml}$ of reaction mixture consisting of $0.1 \mathrm{M}$ sodium phosphate buffer (pH 6.0), $100 \mu \mathrm{l}$ of $50 \mathrm{mM}$ Guaiacol, 100 $\mu 1$ of $12 \mathrm{mM} \mathrm{H}_{2} \mathrm{O}_{2}$. The absorbance was recorded at $436 \mathrm{~nm}$ in 5 minutes. The enzyme activity was calculated by the changes of absorbance per mg protein per minute.

Superoxide dismutase (SOD, EC 1.15.1.1) activity was measured spectrophometrically at $560 \mathrm{~nm}$ according to the method of Beyer and Fridovich (1987). Shortly, $20 \mu 1$ of the crude extract and $20 \mu 1$ of $1 \mathrm{mM}$ riboflavin were added to $2 \mathrm{ml}$ of reaction mixture composed of $50 \mathrm{mM}$ phosphate buffer ( $\mathrm{pH} \mathrm{7.8)} \mathrm{consisting} \mathrm{of} 2 \mathrm{mM}$ EDTA, $0.025 \%$ Triton X-100, $55 \mu \mathrm{M}$ Nitroblue tetrazolium (NBT), and $9.9 \mathrm{mM} \mathrm{L-}$ methionine. One unit of SOD activity (U) was defined as the required enzyme volume to result in $50 \%$ inhibition of the reduction of NBT as recorded at $560 \mathrm{~nm}$. 
Catalase (CAT, EC 1.11.1.6) activity was determined following by Aebi and Lester (1984) method. The 3-ml reaction mixture consisting of $2 \mathrm{ml}$ of leaf extract diluted (x200) in the buffer of $50 \mathrm{mM}$ potassium phosphate $(\mathrm{pH} \mathrm{7.0)}$ ) and $10 \mathrm{mM}$ of hydrogen peroxide. The absorbance decrease at $240 \mathrm{~nm}$ of the reaction was recorded as deposition level of $\mathrm{H}_{2} \mathrm{O}_{2}$. The enzyme activity was expressed as the changes in absorbance per protein concentration per unit time.

\section{Assessment of mycorrhizal colonization of AMF}

Samples for estimating root colonization were collected before harvesting. Five randomly chosen pepper plants from the same treatment were dug out with a soil core of $25 \times 25 \times 25 \mathrm{~cm}$. The roots and the soil were stored in separate plastic bags at $4^{\circ} \mathrm{C}$ until processing within $24 \mathrm{~h}$. Approximately, $500 \mathrm{mg}$ of fine roots from each plant were transferred to separate tubes and were subjected to the staining technique of Vierheilig et al. (1998). Internal fungal structures (hypae, arbuscules, vesicules) were examined under a stereomicroscope at $\times 100$ magnification and the percentage of root length colonized calculated using the gridline intersect method (Giovannetti and Mosse, 1980).

\section{Statistical analysis}

SAS 9.1 (SAS Institute, Cary, North Carolina) package for Windows was used for statistical analysis. All data was evaluated by two-way factorial analysis of variance (ANOVA) and Tukey's Post hoc test at $\mathrm{P}<0.05$.

\section{Results and discussion \\ Mycorrhizal colonization}

AM colonization in mycorrhizae-inoculated plants was remarkably higher than in others without AM inoculation although no significant differences could be found among mycorrhizal treatments (Fig. 1). Interestingly, the combination of three inoculants reached maximum colonization percentage in roots, up to 59\% in Karpia cv. whereas the rates still gained approximately $30 \%$ in no microbial treatment under field conditions. No substantial differences in mycorrhizal colonization rates among pepper cultivars and no interaction between microbial inoculations and cultivars were recorded (Table 2).

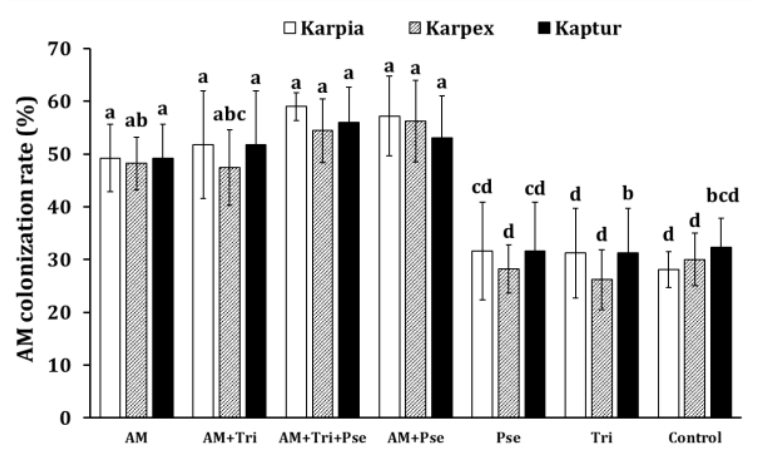

Figure 1. Mycorrhizal colonization of microbial inoculations of three pepper cultivars, Karpia, Karpex, Kaptur. AM, Arbuscular mycorrhizal fungi; Tri, Trichoderma; Pse, Pseudomonas fluorescens. Each bar presents mean \pm standard deviation. Different letters denote significant differences among treatments according to Tukey's post hoc test $(P<0.05)$. 
Table 2. Significance of two main effects (microbial inoculation, $M$ and cultivar, $C$ ) and their interaction between $M$ and $C$ on different parameters.

\begin{tabular}{l|l|l|c}
\hline \multicolumn{1}{c|}{ Parameters } & Microbial inoculation (M) & Cultivar (C) & M x C \\
\hline AM colonization rate & $* * *$ & $\mathrm{~ns}$ & $\mathrm{~ns}$ \\
Fruit yield & $* * *$ & $\mathrm{~ns}$ & $\mathrm{~ns}$ \\
Enzyme activities: & & & \\
PPO & $* * *$ & $* * *$ & $* * *$ \\
POD & $* * *$ & $* * *$ & $* * *$ \\
SOD & $* * *$ & $\mathrm{~ns}$ & $\mathrm{~ns}$ \\
CAT & $* * *$ & $* * *$ & $* * *$ \\
\hline
\end{tabular}

ns, non significant. ***, significant differences at $\mathrm{P}<0.001$ according to Tukey's post hoc test.

\section{Fruit yield}

Inoculation with different microbes alone or together with others altered fruit yield of pepper plants in all pepper cultivars although significant differences depended on specific microbe-cultivar combinations (Table 3). The highest yield was recorded in $\mathrm{AM}+\mathrm{Tri}+\mathrm{Pse}$ combination as the best inoculation in Karpia and Karpex cv., while in Kaptur, the value was highest in plants pretreated by $\mathrm{AM}+\mathrm{Pse}$ as the most enhancing application. Obviously, application of three inoculants gained highest fruit yield when main effect of microbial inoculation was compared statistically, however, microbial applications had greater effect on yield in Karpia and Kaptur (on average, increased $46 \%$ and $51 \%$, respectively, in comparison to their non-inoculation treatment) (Table 3). No interaction between microbial treatment and cultivar in fruit yield was recognized (Table 2).

Table 3. Fruit Yield ( $g$ ) of microbial inoculations of three pepper cultivars (Karpia, Karpex, Kaptur).

\begin{tabular}{l|l|l|l|l}
\hline \multicolumn{1}{c|}{ Treatment } & Karpia & \multicolumn{1}{|c|}{ Karpex } & \multicolumn{1}{c}{ Kaptur } & \multicolumn{1}{c}{$\begin{array}{c}\text { Means of } \\
\text { microbial } \\
\text { inoculations }\end{array}$} \\
\hline AM & $3438 \pm 370 \mathrm{ab}$ & $4267 \pm 934 \mathrm{ab}$ & $3952 \pm 837 \mathrm{ab}$ & $3885 \mathrm{AB}$ \\
AM+Tri & $4068 \pm 195 \mathrm{ab}$ & $4844 \pm 518 \mathrm{ab}$ & $3264 \pm 144 \mathrm{ab}$ & $4058 \mathrm{AB}$ \\
$\mathbf{A M + T r i}+$ Pse & $5310 \pm 619 \mathrm{a}$ & $5382 \pm 229 \mathrm{a}$ & $4066 \pm 291 \mathrm{ab}$ & $4919 \mathrm{~A}$ \\
$\mathbf{A M + P s e}$ & $3844 \pm 465 \mathrm{ab}$ & $4094 \pm 551 \mathrm{ab}$ & $4775 \pm 581 \mathrm{a}$ & $4487 \mathrm{AB}$ \\
Pse & $4430 \pm 902 \mathrm{ab}$ & $4136 \pm 401 \mathrm{ab}$ & $3856 \pm 327 \mathrm{ab}$ & $4085 \mathrm{AB}$ \\
Tri & $3826 \pm 534 \mathrm{ab}$ & $4125 \pm 168 \mathrm{ab}$ & $4089 \pm 137 \mathrm{ab}$ & $4013 \mathrm{AB}$ \\
Control & $2846 \pm 118 \mathrm{~b}$ & $4279 \pm 951 \mathrm{ab}$ & $2647 \pm 545 \mathrm{~b}$ & $3257 \mathrm{~B}$ \\
Means of cultivars & $3882 n s$ & $4445 n s$ & $3799 n s$ & \\
$\begin{array}{l}\text { \% increase due to } \\
\text { microbial inoculation }\end{array}$ & $46 \%$ & $4.6 \%$ & $51 \%$ & \\
\hline
\end{tabular}

AM, Arbuscular mycorrhizal fungi; Tri, Trichoderma; Pse, Pseudomonas fluorescens. Different regular letters denote significant differences among combinations between microbial inoculation and cultivar. Different capital letters present significant differences among means of microbial inoculations. Ns, non significant differences among means of cultivars. All comparisons were followed Tukey's post hoc test $(\mathrm{P}<0.05)$.

The positive effects of beneficial microbes on yield have been described in many studies (Pereira et al., 2015; Yuan et al., 2016; Azarmi et al., 2016; Pascale et al., 2017; 
Yadav et al., 2015). Various reports showed that AM inoculation enhanced fruit yield in pepper plants (Abdel Latef and Chaoxing, 2014; Abdel Latef, 2013; Boonlue et al., 2012; Hernádi et al., 2012; Tanwar et al., 2013) and in tomato (Bakr et al., 2017), which is dissimilar to our result. Pascale et al. (2017) illustrated that Trichoderma harzianum and Trichoderma atroviride improved grape yield and quality while using Pseudomonas fluorescens with organic fertilizer showed maximum enhancement in yield of cucumber (Ahamd et al., 2015). Our results demonstrated that combined three microbes (AM+Tri+Pse) had best increment in fruit yield in Karpia and Karpex cv., which may indicate that there were synergistically beneficial impacts from the microbes on the yield. Several examples of the synergistic effects on biomass were reported in bean plants with AM+Pse (Younesi and Moradi, 2014), in tobacco plants with using Trichoderma harzianum in bioorganic fertilizer and AM fungi (Yuan et al., 2016), greatest growth and yield in sunflower plants when combined using AM, Trichoderma viride and Pse (Yadav et al., 2015). The cumulative benefit of combining multibioinoculants may collectively result from nutrient and water improvement, induced resistance or enhanced tolerance to biotic and/or abiotic stresses, more effective protection from pest and plant diseases under field conditions. Nevertheless, beneficial effects of microbial inoculations on pepper production (Russo, 2006; Russo and Perkins-Veazie, 2010), yield and fruit quality in tomato plants (Bal and Altintas, 2006) were not observed.

\section{Antioxidative and defense enzymes}

The leaf PPO activities were lowered due to Pse inoculation in Karpia and Kaptur, application of AM alone, Tri alone and combination of AM and Pse in three pepper cultivars as compared to their control plants (Fig. 2A). The highest values of PPO were found in the triple inoculated treatments (AM, Tri, Pse), particularly in Karpia the activity of PPO was most pronounced. Dual inoculation of AM and Tri made no changes in the PPO activity of each cultivar $(\mathrm{P}<0.05)$. Using mycorrhizal inoculation alone induced significantly the highest POD activity in leaves of Karpex and Kaptur variety as compared to their control (Fig. 2B). It is worth mentioning that other microbial treatments in Karpia and Kaptur substantially declined or made no change in POD levels while in contrast, AM+Tri and Pse treatment triggered higher POD activities in Karpex. Remarkably, the integrated inoculation of AM, Tri, Pse in Kaptur increased this enzyme level in relation to the control.

AM treatment in Karpia and Kaptur, Tri application in Kaptur variety decreased substantially the leaf SOD activity while the inoculation of Pse in Karpia and Karpex, combination of AM+Tri+Pse in Karpex and Kaptur cultivar increased considerably this enzyme (Fig. 2C). Besides that, other treatments did not change significantly the SOD level compared to their control in each variety. On the other hand, all microbial treatments lowered significantly the CAT activity in leaves except the case of Pse inoculation in Karpex, Tri treatment in Kaptur (Fig. 2D). 

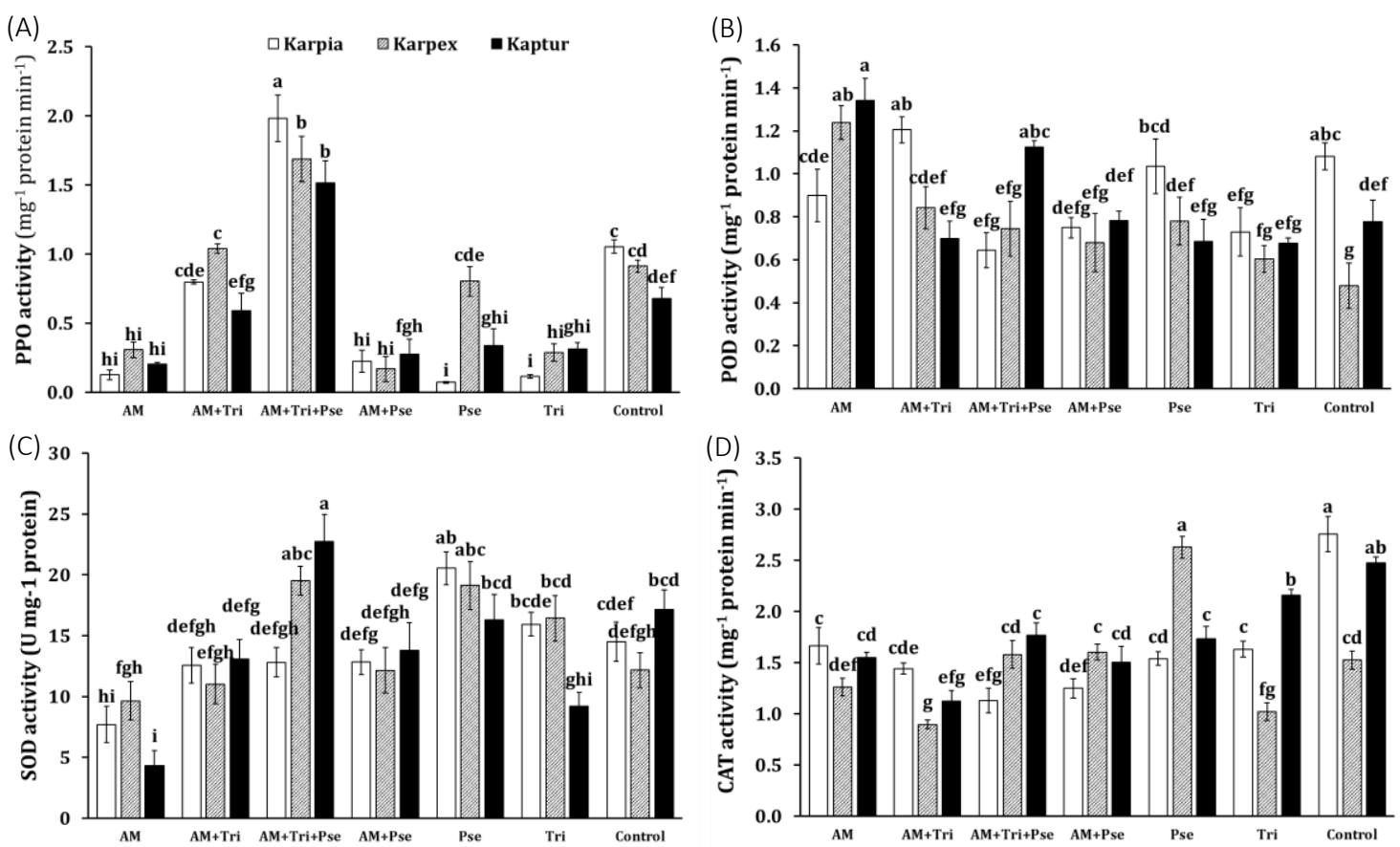

Figure 2. Polyphenol oxidase $(P P O)(A)$, peroxidase $(P O D)(B)$, superoxide dismutase (SOD)

$(C)$, catalase $(C A T)(D)$ activity of microbial treatments in leaves of three pepper cultivars, Karpia, Karpex, Kaptur at 29 days after transplanting. AM, Arbuscular mycorrhizal fungi; Tri, Trichoderma; Pse, Pseudomonas fluorescens. Each bar presents mean \pm standard deviation ( $n$ $=5)$. Different letters denote significant differences among treatments according to Tukey's post hoc test $(P<0.05)$.

Significant differences in the PPO, POD, CAT activities among three pepper varieties were found after 29 days of transplanting (Table 4). Karpex cultivar showed the highest PPO activity whereas strongest POD activity was recorded in Karpia and more dominant CAT activity was in Kaptur. No significant differences in SOD activity among cultivars were observed.

Table 4. Main effects of cultivar on PPO activity in leaves of various microbial inoculations.

\begin{tabular}{c|c|c|c}
\hline Enzyme activities & Karpia & Karpex & Kaptur \\
\hline PPO $\left(\mathrm{mg}^{-1}\right.$ protein min $\left.\mathrm{min}^{-1}\right)$ & $0.62 \mathrm{~b}$ & $0.74 \mathrm{a}$ & $0.57 \mathrm{~b}$ \\
POD $\left(\mathrm{mg}^{-1}\right.$ protein min $\left.{ }^{-1}\right)$ & $0.90 \mathrm{a}$ & $0.76 \mathrm{~b}$ & $0.87 \mathrm{a}$ \\
SOD $\left(\mathrm{U} \mathrm{mg}^{-1}\right.$ protein) & $13.84 \mathrm{~ns}$ & $14.29 \mathrm{~ns}$ & $13.80 \mathrm{~ns}$ \\
CAT $\left(\mathrm{mg}^{-1}\right.$ protein $\left.\mathrm{min}^{-1}\right)$ & $1.63 \mathrm{~b}$ & $1.50 \mathrm{c}$ & $1.75 \mathrm{a}$ \\
\hline
\end{tabular}

ns, non significant. Different letters in each row denote significant differences according to Tukey's post hoc test $(\mathrm{P}<0.05)$ among pepper cultivars.

Under field conditions, plants are frequently confronted with environmental adversities including biotic and abiotic factors during their life. To deal with environmental stresses, plants possess elaborate defense mechanisms that are activated depending on specific stressors, where defense enzymes are essential components in stress-defended responses in plants. Among these enzymes, PPO and POD are crucial ones involved in ligninfication processes and phenols formation, resulting in defense 
barriers for strengthening the plant cell structure (Avdiushko et al., 1993). PPO is usually produced during wounding, pathogen invasion or herbivore attack, considered as plant defense against pathogens, herbivores, also related to ROS generation (Mayer, 2006) whereas POD belongs to Pathogenesis-Related Proteins 9 (PR-9) family, responsive to pathogen invasions (Ray et al., 1998) but can produce as well as scavenge $\mathrm{H}_{2} \mathrm{O}_{2}$ in the first and next phase, respectively (Siegel 2003). ROS mainly consisted of singlet oxygen $\left({ }^{1} \mathrm{O}_{2}^{-}\right)$, superoxide anion radical $\left(\mathrm{O}_{2}{ }^{-}\right)$, hydrogen peroxide $\left(\mathrm{H}_{2} \mathrm{O}_{2}\right)$, and hydroxyl radical $\left({ }^{\circ} \mathrm{OH}\right)$. ROS is also inevitable by-products generated in many normal biochemical pathways in plants. In planta, ROS production and detoxification are balanced under normal metabolic processes, regulated by cellular redox homeostasis (Pospísil, 2012). When plants are subjected to abiotic and biotic stresses ROS is overproduced, breaking the balance, leading to toxification and degradation of lipids, proteins, DNA by their oxidation capacity, eventually causing cell death (Wu et al. 2014; Foyer and Noctor, 2005). To cope with oxidative destruction, plants have developed both ROS non-enzymatic and enzymatic scavengers consisted of SOD and CAT. SOD is the first defense line against ROS (Alscher et al., 2002) owing to its capability of catalyzing the dismutation of $\mathrm{O}_{2}{ }^{--}$to $\mathrm{H}_{2} \mathrm{O}_{2}$ (Wu et al. 2014), then CAT and other antioxidative enzymes detoxify $\mathrm{H}_{2} \mathrm{O}_{2}$ to $\mathrm{H}_{2} \mathrm{O}$ and $\mathrm{O}_{2}$ (Apel and Hirt, 2004). Thus effective activation of these enyzmes can enhance stressed plant tolerance, prevent damages caused by abiotic and biotic stresses.

Our analysed results demonstrated that under field environment application of the AM alone mostly decreased significantly PPO, SOD, CAT activity in leaves of all varieties as compared to their controls (Table 5, Fig. 2A, 2C, 2D), which is in line with observations of Kohler et al. (2009), Mollavali et al. (2016), Minton et al. (2016). The finding may suggest that pepper plants gained benefits such as nutrient and water improvements from the symbiosis with the AM, therefore, might produce less ROS, then lower the defense enzymes. On the other hand, inoculation of AM also triggered highest POD levels (Table 5), particularly in Karpex and Kaptur cultivar (Fig. 2B), which is consistent with a result in pepper plants under salinity stress (Abdel Latef and Chaoxing, 2014). In contrast with our results, other studies show mycorrhizal treatments stimulated antioxidative enzymes in leaves of various plants (Pedranzani et al., 2015; Chu et al., 2016; Jiang et al., 2016; Hashem et al., 2016; Sarkar et al., 2016) in pepper plants such as CAT when plants exposed to $1 \mathrm{mM} \mathrm{NaCl}$ in the long term (Cekic et al., 2012), SOD under salinity stress (Abdel Latef and Chaoxing, 2014).

Table 5. Main effects of microbial inculation on defense enzymes activity in leaves of three pepper varieties.

\begin{tabular}{l|c|c|c|c|c|c|c}
\hline $\begin{array}{l}\text { Defense enzyme } \\
\text { activity }\end{array}$ & AM & AM+Tri & AM+Tri+Pse & AM+Pse & Pse & Tri & Control \\
\hline $\begin{array}{l}\text { PPO }\left(\mathrm{mg}^{-1} \text { protein }\right. \\
\left.\mathrm{min}^{-1}\right)\end{array}$ & $0.21 \mathrm{~d}$ & $0.81 \mathrm{~b}$ & $1.72 \mathrm{a}$ & $0.26 \mathrm{~d}$ & $0.40 \mathrm{c}$ & $0.23 \mathrm{~d}$ & $0.88 \mathrm{~b}$ \\
$\begin{array}{l}\mathrm{POD}\left(\mathrm{mg}^{-1} \text { protein }\right. \\
\left.\mathrm{min}^{-1}\right)\end{array}$ & $1.16 \mathrm{a}$ & $0.91 \mathrm{~b}$ & $0.84 \mathrm{bc}$ & $0.73 \mathrm{~cd}$ & $0.83 \mathrm{bc}$ & $0.67 \mathrm{~d}$ & $0.78 \mathrm{~cd}$ \\
$\begin{array}{l}\mathrm{SOD}\left(\mathrm{U} \mathrm{mg} \mathrm{mg}^{-1}\right. \\
\text { protein })\end{array}$ & $7.22 \mathrm{c}$ & $12.22 \mathrm{~b}$ & $18.35 \mathrm{a}$ & $12.93 \mathrm{~b}$ & $18.67 \mathrm{a}$ & $13.85 \mathrm{~b}$ & $14.60 \mathrm{~b}$ \\
$\begin{array}{l}\mathrm{CAT}\left(\mathrm{mg}^{-1} \text { protein }\right. \\
\left.\mathrm{min}^{-1}\right)\end{array}$ & $1.49 \mathrm{c}$ & $1.15 \mathrm{~d}$ & $1.49 \mathrm{c}$ & $1.45 \mathrm{c}$ & $1.96 \mathrm{~b}$ & $1.60 \mathrm{c}$ & $2.25 \mathrm{a}$ \\
\hline
\end{tabular}

AM, Arbuscular mycorrhizal fungi; Tri, Trichoderma; Pse, Pseudomonas fluorescens. Different letters in each row denote significant differences among microbial treatments according to Tukey's post hoc test $(\mathrm{P}<0.05)$. 
The plant growth promoting bacteria Pse lessened significantly PPO and CAT in leaves, compared to the control, however, SOD activity were greatly increased (Table 5), particularly in Karpia and Karpex variety (Fig. 2C) whilst POD remained unchanged in Pse pretreated plants with exception of the higher increase in Karpex (Table 5, Fig. 2B). Azarmi et al. (2016) showed that pistachio seedlings inoculated by Pseudomonas fluorescens triggered significant increases in PPO, POD, SOD, CAT ativities in leaves under $\mathrm{Zn}$ and $\mathrm{NaCl}$ stresses. By contrast, soybean plants treated by Pseudomonas sp. reduced considerably CAT, PPO, SOD, POD activity in leaves in comparison with the non-inoculated plants (Kumari et al., 2015). Apparently, the combination of these bacteria with AM decreased significantly the activities of all enzymes in relation with its counterpart in Pse inoculation alone (Table 5). This observation is in accordance with the report of Kohler et al. (2008) that combination of Rhizophagus irregularis or Funneliformis mosseae with Pseudomonas mendocina Palleroni dropped SOD, CAT level in leaves of Lactuca saiva L. under severe drought stress. However, POD activity in our results is in contrast to that of the authors. This might suggest a complex and specific interaction between plants and microbial partners under particular stresses.

Application of Tri reduced PPO, CAT activities but remained unchanged POD, SOD levels (Table 5), which is inconsistent with a previous study in maze plants under drought stress (Guler et al., 2016). Instead of decreasing PPO, SOD activity in leaves as AM plants did, AM+Tri did not change considerably PPO, SOD levels whereas, intriguingly, these enzyme activities in the three-inoculant treatment (AM+Tri+Pse) leaped (Table 5). In detail, integrated AM+Tri+Pse induced highest PPO in all cultivars (Fig. 2A), relatively high POD level in Kaptur (Fig. 2B), highest SOD in Karpex and Kaptur (Fig. 2C). The reasons for these increases may be that multiple inoculation with three different microbes activated the host plant defense system greater than single or dual inoculation did before plants recognized the applied microbes as non-pathogenic ones, then host plants might take an advantage of the induced/primed defense system as an important mechanism to protect themselves against unfavoured conditions in the field. Several workers reported that application of Trichoderma spp. can improve defense enzymes in plants (Guler et al., 2016; Gajera et al., 2016) and co-inoculation of AM fungi and Trichoderma spp. have synergistic impacts on controlling phytopathogens (Saldajeno et al., 2008; Martínez-Medina et al., 2009; Srivastava et al., 2010). Yuan et al. (2016) illustrated that plants inoculated by Glomus mosseae or Trichoderma harzianum amended bioorganic fertilizer elevated significantly PPO and POD activity; however, the co-inoculation gained the highest PPO and POD level as compared to the non-inoculated control.

Overall, our findings highlighted different responses among pepper genotypes to impacts of microbial inoculants on yield and defense enzymes activities. AM, Tri, Pse, well known as plant performance enhancers can influence the pool of enzymatic scavengers, defense enzymes and positively impact on fruit yield in all pepper varieties. In fact, PPO, POD, SOD and CAT activity of the microbial treatments in our experiment were different from non-microbe plants. The differences in microbe-induced enzymes activities even took place among cultivars, which may be due to host genetic variation among pepper varieties, compatibility of interaction between microbe and pepper genotype. Noticeably, effectiveness of the applied microorganisms and their combinations were not always defense stimulators under field conditions. Inconsistent results in defense enzymes from previous studies may be originated from different experiment conditions that most work were implemented in controlled environments, 
different species and/or strains of microbes applied, specific microbe-cultivar associations. Indeed, in field environment, many stresses can occur simultaneously and are associated to complicated interactions among biotic, abiotic and edaphic environments, thus plants often tolerate combinations of different stresses. Modulation of plant defense system by the beneficial microbes utilized could be an important gainful impact of plants cultivated under field conditions, which might lead to better plant protection from various stresses, eventually increased fruit yield in pepper plants. In this study, specific interactions between microbe as well as their combination and pepper genotype were also observed, which was described in many studies (Sensoy et al., 2007; Cekic et al., 2012).

In conclusion, each beneficial microbe and their combined inoculations have a different potential to modulate defense enzymes and positively influence on fruit yield under field conditions. Karpia and Kaptur variety gained more beneficial effects from microbial inoculations on yield than Karpex. Remarkably, using combination of three different microbes (AM+Tri+Pse) generally gained synergic results in induction of defense enzymes as well as enhanced yield, which may be due to collective mechanisms of host protection induced by three diverse inoculants.

Acknowledgements. Authors thank to Stipendium Hungaricum fellowship for supporting this study.

\section{REFERENCES}

[1] Abdel Latef, A.A. (2013): Growth and some physiological activities of pepper (Capsicum annuит L.) in response to cadmium stress and mycorrhizal symbiosis. - Journal of Agricultural Science and Technology 15: 1437-1448.

[2] Abdel Latef, A.A.H., Chaoxing, H. (2014): Does inoculation with Glomus mosseae improve salt tolerance in pepper plants? - Journal of Plant Growth Regulation 33(3): 644653.

[3] Aebi, H., Lester, P. (1984): Catalase in vitro. - Methods in Enzymology 105: 121-126.

[4] Ahamd, M., Zeshan, M.S.H., Nasim, M., Zahir, Z.A., Nadeem, S.M., Nazli, F., Jamil, M. (2015): Improving the productivity of cucumber through combined application of organic fertilizers and Pseudomonas fluorescens. - Pakistan Journal of Agricultural Sciences 52(4): 1011-1016.

[5] Ahemad, M., Kibret, M. (2014): Mechanisms and applications of plant growth promoting rhizobacteria: Current perspective. - Journal of King Saud University - Science 26: 1-20.

[6] Alscher, R.G., Erturk, N., Heath, L.S. (2002): Role of superoxide dismutases (SODs) in controlling oxidative stress in plants. - Journal of Experimental Botany 53(372): 13311341.

[7] Apel, K., Hirt, H. (2004): Reactive oxygen species: Metabolism, oxidative Stress, and signal transduction. - Annual Review of Plant Biology 55(1): 373-399.

[8] Avdiushko, S.A., Ye, X.S., Kuc, J. (1993): Detection of several enzymatic activities in leaf prints of cucumber plant. - Physiological and Molecular Plant Pathology 42: 441454.

[9] Azarmi, F., Mozafari, V., Dahaji, P.A., Hamidpour, M. (2016): Biochemical, physiological and antioxidant enzymatic activity responses of pistachio seedlings treated with plant growth promoting rhizobacteria and Zn to salinity stress. - Acta Physiologiae Plantarum 38: 21.

[10] Azcón-Aguilar, C., Barea, J.M. (1997): Applying mycorrhiza biotechnology to horticulture: significance and potentials. - Scientia Horticulturae 68: 1-24. 
[11] Bakr, J., Daood, H.G., Pék, Z., Helyes, L., Posta, K. (2017): Yield and quality of mycorrhized processing tomato under water scarcity. - Applied Ecology and Environmental Research 15(1): 401-413.

[12] Bal, U., Altintas, S. (2006): Effects of Trichoderma harzianum on the yield and fruit quality of tomato plants (Lycopersicon esculentum) grown in an unheated greenhouse. Australian Journal of Experimental Agriculture 46(1): 131-136.

[13] Beyer, W.F., Fridovich, I. (1987): Assaying for superoxide dismutase activity: some large consequences of minor changes in conditions. - Analytical Biochemistry 161: 559-566.

[14] Boonlue, S., Surapat, W., Pukahuta, C., Suwanarit, P., Suwanarit, A., Morinaga, T. (2012): Diversity and efficiency of arbuscular mycorrhizal fungi in soils from organic chili (Capsicum frutescens) farms. - Mycoscience 53: 10-16.

[15] Bradford, M.M. (1976): A rapid and sensitive method for the quantitation of microgram quantities of protein utilizing the principle of protein-dye binding. - Analytical Biochemistry 72: 248-254.

[16] Cekic, F.O., Unyayar, S., Ortas, I. (2012): Effects of arbuscular mycorrhizal inoculation on biochemical parameters in Capsicum annuum grown under long term salt stress. Turkish Journal of Botany 36(1): 63-72.

[17] Chandanie, W.A., Kubota, M., Hyakumachi, M. (2009): Interaction between the arbuscular mycorrhizal fungus Glomus mosseae and plant growth-promoting fungi and their significance for enhancing plant growth and suppressing damping-off of cucumber (Cucumis sativus L.). - Applied Soil Ecology 41: 336-341.

[18] Chu, X.T., Fu, J.J., Sun, Y.F., Xu, Y.M., Miao, Y.J., Xu, Y.F., Hu, T.M. (2016): Effect of arbuscular mycorrhizal fungi inoculation on cold stress-induced oxidative damage in leaves of Elymus nutans Griseb. - South African Journal of Botany 104: 21-29.

[19] Datnoff, L.E., Nemec, S., Pernezny, K. (1995): Biological control of Fusarium crown and root rot of tomato in Florida using Trichoderma harzianum and Glomus intraradices. Biological Control 5: 427-431.

[20] Elad, Y. (1996): Mechanisms involved in the biological control of Botrytis cinerea incited diseases. - European Journal of Plant Pathology 102: 719-732

[21] Fehrmann H., Dimond, A.E. (1967): Peroxidase activity and phytophthora resistance in different organs of the potato plant. - Phytopathology 57: 69-72.

[22] Foyer, C.H., Noctor, G. (2005): Oxidant and antioxidant signalling in plants: a reevaluation of the concept of oxidative stress in a physiological context. - Plant Cell Environment 28: 1056-1071.

[23] Gajanayake, B., Trader, B.W., Reddy, K.R., Harkess, R.L. (2011): Screening ornamental pepper cultivars for temperature tolerance using pollen and physiological parameters. HortScience 46: 878-884.

[24] Gajera, H.P., Katakpara, Z.A., Patel, S.V., Golakiya, B.A. (2016): Antioxidant defense response induced by Trichoderma viride against Aspergillus niger Van Tieghem causing collar rot in groundnut (Arachis hypogaea L.). - Microbial Pathogenesis 91: 26-34.

[25] Gaur, A., Adholeya, A., Mukerji, K.G. (1998): A comparison of AM fungi inoculants using Capsicum and Polianthes in marginal soil amended with organic matter. Mycorrhiza 7: 307-312.

[26] Giovannetti, M ., Mosse, B. (1980): An evaluation of techniques for measuring vesiculararbuscular mycorrhizal infection in roots. - New Phytologist 84: 489-500.

[27] Green, H., Larsen, J., Olsson, P.A., Jensen, D.F., Jakobsen, I. (1999): Suppression of the biocontrol agent Trichoderma harzianum by mycelium of the arbuscular mycorrhizal fungus Glomus intraradices in root-free soil. - Applied and Environmental Microbiology 65: 1428-1434.

[28] Guler, N.S., Pehlivan, N., Karaoglu, S.A., Guzel, S., Bozdeveci, A. (2016): Trichoderma atroviride ID20G inoculation ameliorates drought stress-induced damages by improving antioxidant defence in maize seedlings. - Acta Physiologiae Plantarum 38(6): 132. 
[29] Hashem, A., Abd_Allah, E. F., Alqarawi, A.A., Al Huqail, A.., Egamberdieva, D., Wirth, S. (2016): Alleviation of cadmium stress in Solanum lycopersicum L. by arbuscular mycorrhizal fungi via induction of acquired systemic tolerance. - Saudi Journal of Biological Sciences 23(2): 272-281.

[30] Harinasut, P., Poonsopa, D., Roengmongkol, K., Charoensataporn, R. (2003): Salinity effects on antioxidant enzymes in mulberry cultivar. - ScienceAsia 29: 109-113.

[31] Hernádi, I., Sasvári, Z., Albrechtová, J., Vosátka, M., Posta, K. (2012): Arbuscular mycorrhizal inoculant increases yield of spice pepper and affects the indigenous fungal community in the field. - HortScience 47(5): 603-606.

[32] Jiang, Q.-Y., Tan, S.-Y., Zhuo, F., Yang, D.-J., Ye, Z.-H., Jing, Y.-X. (2016): Effect of Funneliformis mosseae on the growth, cadmium accumulation and antioxidant activities of Solanum nigrum. - Applied Soil Ecology 98: 112-120.

[33] Jiang, M., Zhang, J. (2001): Effect of abscisic acid on active oxygen species, antioxidative defence system and oxidative damage in leaves of maize seedlings. - Plant \& Cell Physiology 2: 1265-1273.

[34] Jung, S.C., Martinez-Medina, A., Lopez-Raez, J.A., Pozo, M.J. (2012): MycorrhizaInduced Resistance and Priming of Plant Defenses. - Journal of Chemical Ecology 38(6): 651-664.

[35] Kaya, C., Ashraf, M., Sonmez, O., Aydemir, S., Tuna, A.L., Cullu, M.A. (2009): The influence of arbuscular mycorrhizal colonisation on key growth parameters and fruit yield of pepper plants grown at high salinity. - Scientia Horticulturae 121(1): 1-6.

[36] Kohler, J., Hernández, J.A., Caravaca, F., Roldán, A. (2008): Plant-growth-promoting rhizobacteria and arbuscular mycorrhizal fungi modify alleviation biochemical mechanisms in water-stressed plants. - Functional Plant Biology 35(2): 141-151.

[37] Kumari, S., Vaishnav, A., Jain, S., Varma, A., Choudhary, D.K. (2015): Bacterialmediated induction of systemic tolerance to salinity with expression of stress alleviating enzymes in soybean (Glycine max L. Merrill). - Journal of Plant Growth Regulation 34(3): 558-573.

[38] López-Ráez, J.A., Verhage, A., Fernández, I., García, J.M., Azcón-Aguilar, C., Flors, V., Pozo, M.J. (2010): Hormonal and transcriptional profiles highlight common and differential host responses to arbuscular mycorrhizal fungi and the regulation of the oxylipin pathway. - Journal of Experimental Botany 61(10): 2589-2601.

[39] López, P., Gorzalczany, S., Acevedo, C., Alonso, R., Ferraro, G. (2012): Chemical study and anti-inflammatory activity of Capsicum chacoense and C. baccatum. - Brazilian Journal of Pharmacognosy 22(2): 455-458.

[40] Lugtenberg, B., Kamilova, F. (2009): Plant-Growth-Promoting Rhizobacteria. - Annual Review of Microbiology 63(1): 541-556.

[41] Malik, A.A., Chattoo, M.A., Sheemar, G., Rashid, R. (2011): Growth, yield and fruit quality of sweet pepper hybrid SH-SP-5 (Capsicum annuum L.) as affected by integration of inorganic fertilizers and organic manures (FYM). - Journal Agricultural Technology 7(4): 1037-1048.

[42] Martínez-Medina, A., Pascual, J.A., Lloret, E., Roldán, A. (2009): Interactions between arbuscular mycorrhizal fungi and Trichoderma harzianum and their effects on Fusarium wilt in melon plants grown in seedling nurseries. - Journal of the Science of Food and Agriculture 89: 1843-1850.

[43] Martinez, A., Obertello, M., Pardo, A., Ocampo, J.A., Godeas, A. (2004): Interactions between Trichoderma pseudokoningii strains and the arbuscular mycorrhizal fungi Glomus mosseae and Gigaspora rosea. - Mycorrhiza 14: 79-84.

[44] Mayer, A.M. (2006): Polyphenol oxidases in plants and fungi: going places? A review. Phytochemistry 67: 2318-2331.

[45] McAllister, C.B., García-Romera, I., Godeas, A., Ocampo, J.A. (1994): Interactions between Trichoderma koningii, Fusarium solani and Glomus mosseae: effects on plant 
growth, arbuscular mycorrhizas and the saprophyte inoculants. - Soil Biology and Biochemistry 26: 1363-1367.

[46] Minton, M.M., Barber, N.A., Gordon, L.L. (2016): Effects of arbuscular mycorrhizal fungi on herbivory defense in two Solanum (Solanaceae) species. - Plant Ecology and Evolution 149(2): 157-164.

[47] Mollavali, M., Bolandnazar, S.A., Schwarz, D., Rohn, S., Riehle, P., Nahandi, F.Z. (2016). Flavonol glucoside and antioxidant enzyme biosynthesis affected by mycorrhizal fungi in various cultivars of onion (Allium cepa L.). - Journal of Agricultural and Food Chemistry 64(1): 71-77.

[48] Pascale, A., Vinale, F., Manganiello, G., Nigro, M., Lanzuise, S., Ruocco, M., ... Lorito, M. (2017): Trichoderma and its secondary metabolites improve yield and quality of grapes. - Crop Protection 92: 176-181.

[49] Pedranzani, H., Rodríguez-Rivera, M., Gutiérrez, M., Porcel, R., Hause, B., Ruiz-Lozano, J.M. (2016): Arbuscular mycorrhizal symbiosis regulates physiology and performance of Digitaria eriantha plants subjected to abiotic stresses by modulating antioxidant and jasmonate levels. - Mycorrhiza 26(2): 141-152.

[50] Pereira, J.A.P., Vieira, I.J.C., Freitas, M.S.M., Prins, C.L., Martins, M.A., Rodrigues, R. (2015): Effects of arbuscular mycorrhizal fungi on Capsicum spp. - The Journal of Agricultural Science 154(5): 828-849.

[51] Polovnikova, M.G., Voskresenskaya, O.L. (2008): Activities of antioxidant system components and polyphenol oxidase in ontogeny of lawn grasses under megapolis conditions. - Russian Journal of Plant Physiology 55(5): 699-705.

[52] Pospísil, P. (2012): Molecular mechanisms of production and scavenging of reactive oxygen species by photosynthem II. - Biochimica et Biophysica Acta 1817: 218-231.

[53] Rathmell, W.G., Sequeira, L. (1974): Soluble peroxidase in fluid from the intercellular spaces of tobacco leaves. - Plant Physiology 53: 317-318.

[54] Ray, H., Douches, D.S., Hammerschmidt, R. (1998): Transformation of potato with cucumber peroxidase: Expression and disease response. - Physiological and Molecular Plant Pathology 53: 93-103

[55] Russo, V.M. (2006): Biological amendment, fertilizer rate, and irrigation frequency for organic bell pepper transplant production. - HortScience 41: 1402-1407.

[56] Russo, V.M. Perkins-Veazie, P. (2010): Yield and nutrient content of bell pepper pods from plants developed from seedlings inoculated, or not, with microorganisms. HortScience 45: 352-358.

[57] Sarkar, J., Ray, A., Chakraborty, B., Chakraborty, U. (2016): Antioxidative changes in Citrus reticulata $\mathrm{L}$. induced by drought stress and its effect on root colonization by arbuscular mycorrhizal fungi. - European Journal of Biological Research 6(1): 1-13.

[58] Saldajeno, M.G.B., Chandanie, W.A., Kubota, M., Hyakumachi, M. (2008): Effects of interactions of arbuscular mycorrhizal fungi and beneficial saprophytic mycoflora on plant growth and disease protection. In: Siddiqui, Z.A., Akhtar, M.S., Futai, K. (eds.), Mycorrhizae: Sustainable Agriculture and Forestry. Springer Sciences, Netherlands, 211226.

[59] Sensoy, S., Demir, S., Turkmen, O., Erdinc, C., Savur, O. (2007): Responses of some different pepper (Capsicum anпuит L.) genotypes to inoculation with two different arbuscular mycorrhizal fungi. - Scientia Horticulturae 113(1): 92-95.

[60] Siddiqui, Z.A., Mahmood, I. (1996): Effects of Heterodera cajani, Meloidogyne incognita and Fusarium udum on the wilt disease complex of pigeon pea. - Indian Journal of Nematology 26: 102-104.

[61] Siegel, B.Z. (2003): Plant peroxidases - an organic perspective. - Plant Growth Regulation 12: 303-312.

[62] Singh, L.P., Gill, S.S., Tuteja, N. (2011): Unraveling the role of fungal symbionts inplant abiotic stress tolerance. - Plant Signaling and Behavior 6: 175-191. 
[63] Sivasithamparam, K., Ghisalberti, E.L. (1998): In: Kubicek, C.P., Harman, G.E. (eds) Trichoderma and Gliocladium, Taylor and Francis, London 1: 139-191.

[64] Smith, S.E., Read, D.J. (2008): Mycorrhizal symbiosis. 3rd edn. Academic Press

[65] Srivastava, R., Khalid, A., Singh, U.S., Shama, A.K. (2010): Evaluation of arbuscular mycorrhizal fungus, fluorescent Pseudomonas and Trichoderma harzianum formulation against Fusarium oxysporum F. sp. lycopersici for the management of tomato wilt. Biological Control 53: 24-31.

[66] Tanwar, A., Aggarwal, A., Kadian, N. Gupta, A. (2013): Arbuscular mycorrhizal inoculation and super phosphate application influence plant growth and yield of Capsicum annuum. - Journal of Soil Science and Plant Nutrition 13: 55-66.

[67] Vierheilig, H., Coughlan, A.P., Wyss, U., Piché, Y. (1998): Ink and vinegar, a simple staining technique for arbuscular-mycorrhizal fungi. - Applied and Environmental Microbiology 64: 5004-5007

[68] Vosátka, M., Albrechtová, J. (2008): Theoretical aspects and practical uses of mycorrhizal technology in floriculture and horticulture. In: Teixeira da Silva, J.A. (ed.). Floriculture, ornamental and plant biotechnology. Advances and topical issues. Glob. Sci. Books Ltd., Takamatsu, Japan. 466-479

[69] Wu, Q.S., Zou, Y.N., Abd_Allah, E.F. (2014): Mycorrhizal Association and ROS in Plants. In: P. Ahmad (ed): Oxidative Damage to Plants. Elsevier Inc. 453- 475.

[70] Yadav, A., Yadav, K., Aggarwal, A. (2015): Impact of Arbuscular Mycorrhizal Fungi with Trichoderma viride and Pseudomonas fluorescens on Growth, Yield and Oil Content in Helianthus annuus L. - Journal of Essential Oil Bearing Plants 18(2): 444-454.

[71] Yang, Z.H., Wang, X.H., Wang, H.P., Hu, L.Q., Zheng, X.M., Li, S.W. (2010): Capsaicin mediates cell death in bladder cancer T24 cells through reactive oxygen species production and mitochondrial depolarization. - Urology 75(3): 735-741.

[72] Younesi, O., Moradi, A. (2014): Effects of plant growth-promoting rhizobacterium (PGPR) and arbuscular mycorrhizal fungus (AMF) on antioxidant enzyme activities in salt-stressed bean (Phaseolus vulgaris L.). - Agriculture 60(1): 10-21.

[73] Yuan, S., Li, M., Fang, Z., Liu, Y., Shi, W., Pan, B., ... Shen, Q. (2016): Biological control of tobacco bacterial wilt using Trichoderma harzianum amended bioorganic fertilizer and the arbuscular mycorrhizal fungi Glomus mosseae. - Biological Control 92: 164-171.

[74] Zimand, G., Elad, Y., Chet, I. (1996): Effect of Trichoderma harzianum on Botrytis cinerea pathogenicity. - Phytopathology 86: 1255-1260. 